\title{
Hito Steyerl. Cyfrowy realizm i praca muzeum
}

Andrzej Leśniak

TEKSTY DRUGIE 2020, NR 4, S. 50-66

DOI: $10.18318 /$ td.2020.4.4 | ORCID: 0000-0003-2654-0219

$\mathbf{H}$

ito Steyerl jest artystką docenianą i fetowaną. W prestiżowym rankingu ArtReview pojawiła się po raz pierwszy w 2013 roku, na 69 pozycji, i bardzo szybko awansowała.W 2017 roku znalazła się na jego szczycie, a w zeszłorocznej edycji zajęła czwarte miejsce, wyprzedzona jedynie przez Glenna Lowry'ego, dyrektora MoMa w Nowym Jorku, Nan Goldin i małżeństwo Wirthów prowadzące jedną z najważniejszych sieci galerii na świecie. Oczywiście pozycja w rankingu nie rozstrzyga o jakości artystycznej czy wadze teoretycznej, natomiast trudno odmówić temu wskaźnikowi jakiejkolwiek mocy symbolicznej. W niniejszym tekście spróbuję pokazać, jakie są źródła takiego statusu artystki. Odwołując się do pojęcia realizmu zredefiniowanego niedawno w kontekście pola sztuki przez Nicolasa Bourriauda i do sformułowanej przez Luca Boltanskiego i Arnauda Esquerre'a koncepcji wzbogacania jako dominującej logiki współczesnej fazy rozwoju gospodarki, pokażę, że w jej praktyce podstawowa jest relewantność - zdolność do analizy kluczowych problemów rzeczywistości: od zagadnień cyfrowej wizualności po rolę instytucji muzealnych w systemie kapitalistycznym.

Andrzej Leśniak profesor instytutu w Instytucie Badań Literackich Polskiej Akademii Nauk. Autor trzech książek: Ikonofilia. Francuska semiologia pikturalna iobrazy (2013); Obraz płynny. Georges Didi-Huberman i dyskurs historii sztuki (2010); Topografie doświadczenia: Maurice Blanchot i lacques Derrida (2003). Redaktor (wspólnie z Grzegorzem Piątkiem) zbioru tekstów Rema Koolhaasa (Śmieciowa przestrzeń. Teksty, 2017) oraz polskich wydań Le Corbusiera (Kiedy katedry były białe, 2013 i Wstronę architektury, 2012). 
Steyerl wydaje się szczególnie istotna z perspektywy humanistyki jako artystka łącząca praktykę z teorią, tworzenie obiektów artystycznych, rzeczy, instalacji, filmów prezentowanych w kontekście muzealnym lub galeryjnym z pisaniem. Jej teksty nie przestrzegają konwencji akademickich, lecz mimo to są bardzo dobrze zakorzenione w dyskusjach współczesnej humanistyki. Steyerl dużo publikuje, a jej eseje są czymś więcej niż uzupełnieniem wystaw czy eksplikacją założeń jej prac. W rozmowie z Łukaszem Zarembą tłumaczy relację między tymi dwiema sferami działalności:

Uczono mnie, że obraz nigdy nie powinien ilustrować tekstu; podobnie staram się myśleć o swoim pisaniu - ono również nie powinno ilustrować moich obrazów. Powinno istnieć między nimi napięcie. Chodzi zatem o utrzymywanie napięcia i szanowanie autonomii każdej z form wypowiedzi. ${ }^{1}$

Teksty i dzieła mają więc być powiązane, nie istnieją jednak w relacji podległości: ilustracyjność należy tu rozumieć prawdopodobnie jako podległość. Steyerl jest artystką, która nie tylko uprawia praktykę refleksyjną, zmuszającą do przemyśleń i potencjalnie generującą teorię, ale też sama eksperymentuje z formami pisarskimi, przede wszystkim z esejem, w ramach którego myśl pojawia się autonomicznie wobec działań artystycznych. Napięcie między dwiema płaszczyznami wyrazu sprawia, że lektura Steyerl odsyła czytelnika do prac artystycznych; jednocześnie oglądanie jej dzieł, zawsze opartych na wyrazistych konceptach, krytycznych, analitycznych wobec rzeczywistości, wydaje się wymagać dopełnienia tekstualnego, jakiejś formy dyskursu, która dawałaby szansę na pogłębioną refleksję. Mamy tu do czynienia z oscylacją między dwiema aktywnościami. Być może najłatwiej zrozumieć tę sytuację, odwołując się do tezy Haruna Farockiego (sformułowanej zresztą w rozmowie ze Steyerl), zgodnie z którą warunkiem możliwości tworzenia wiedzy w obszarze filmu jest powtórzenie. „Filmowcy dokumentalni nie mają własnego obszaru kompetencji albo wiedzy. Muszą więc się powtarzać - tylko dzięki powtórzeniu gromadzi się wiedza"2. Twórczość Steyerl w istocie opiera się na powtórzeniach: oscylacje między sztuką i tekstami mają charakter

1 Ł. Zaremba Działać jako piksel. Rozmowa z Hito Steyerl, "Magazyn Szum”, grudzień 2014, https:// magazynszum.pl/dzialac-jako-piksel-rozmowa-z-hito-steyerl/ (15.02.2020).

2 H. Farocki, H. Steyerl A Magical Imitation of Reality, w: J. Fiduccia Cahier \# 2, Kaleidoscope Press, Mediolan 2011, s. 25. 
repetycji tematów i perspektyw. Refleksja wydaje się powstawać nie dzięki ścisłej metodzie (co z oczywistych przyczyn byłoby niemożliwe zarówno w przypadku obiektu artystycznego, jak i eseju), ale na mocy nagromadzenia motywów, niemal obsesyjnych powrotów do kwestii, od których nie ma ucieczki. Steyerl pisze eseje, w których mierzy się z kluczowymi problemami kultury wizualnej, takimi jak funkcjonowanie w społeczeństwie nadzoru, status archiwów, dokumentalność, możliwość krytyki porządku polityczno-ekonomicznego, globalizacja. Chciałbym pokazać, że jej podejście - postawa badawcza rozpięta między praktyką artystyczną, w której powracają najbardziej istotne problemy kultury wizualnej, i pisarstwem opartym na eksploracji powracających, nieusuwalnych problemów współczesności - opiera się na pragnieniu relewancji, odniesienia do rzeczywistości, możliwie dobrego zakorzenienia własnej pracy w tym, co istotne, wymagające interwencji albo krytycznego namysłu. Steyerl dziedziczy tym samym postawę tych artystów, którzy upatrywali sensu własnej pracy w krytycznych interwencjach, w takiej pracy z materiałem wizualnym, która polega na jego rekonfiguracji pozwalającej na lepsze zrozumienie, wypracowanie perspektywy alternatywnej dla najbardziej rozpowszechnionych sposobów myślenia. Nieprzypadkowe jest powyższe odwołanie do Haruna Farockiego, artysty i filmowca, którego zaangażowanie polityczne najłatwiej byłoby określić właśnie za pomocą odwołania do pojęcia interwencji: pojedynczego aktu rekonfiguracji wizualności, zawsze w celu krytycznym i zawsze w bliskiej relacji wobec tego, co definiuje rzeczywistość.

Praktyka Steyerl - wywodząca się wprost z tradycji sztuki zaangażowanej - zyskuje znaczenie dzięki swej relewantności: zdolności do odnoszenia się do tego, co realne. Odpowiada tym samym na dającą się zaobserwować w sztuce palącą potrzebę zakorzenienia w rzeczywistości, na łatwy do zdiagnozowania kryzys, którego dojmująca obecność jest bardzo dobrze uzasadniona naszym codziennym doświadczeniem i wiedzą dotyczącą funkcjonowania sztuki jako instytucji. Globalny system sztuki ustrukturowany dzięki biennale, targom o światowym zasięgu, sieci wpływowych galerii i muzeów opiera się na autonomicznym i jednocześnie niezrozumiałym „z zewnątrz” systemie kreacji wartości ${ }^{3}$. Wytwarza on niewidzialną, ale równocześnie niemożliwą do sforsowania granicę między globalnym systemem sztuki i tym

3 Zob. L. Boltanski Od rzeczy do dzieła. Procesy atrybucji i nadawania wartości przedmiotom, w: Wieczna radość. Ekonomia polityczna społecznej kreatywności, red. M. Kozłowski, A. Kurant, J. Sowa, K. Szadkowski, J. Szreder, Bęc Zmiana, Warszawa 2011. 
wszystkim, co nie wchodzi w jego skład. Jak dobrze wiemy, ów autonomiczny system kreacji wartości z racji swej niezrozumiałości (przynajmniej w perspektywy „zewnętrznej”) jest doskonałą pożywką teorii spiskowych i nieufności wobec sztuki nowoczesnej i współczesnej. Co więcej, staje się bardzo łatwo zarzewiem konfliktów o charakterze wojen kulturowych; w polskim kontekście mieliśmy do czynienia z zapowiedziami tego rodzaju starć w felietonowych działaniach krytyków sztuki funkcjonujących na marginesie głównego nurtu świata sztuki: Moniki Małkowskiej czy Andrzeja Biernackiego. Dopiero niedawno taka wizja artworldu, okraszona jeszcze oskarżeniem o lewicową dominację ideologiczną $\mathrm{w}$ ramach artystycznego mainstreamu, weszła do głównego nurtu dyskusji w polu kultury dzięki nominacji Piotra Bernatowicza na stanowisko dyrektora warszawskiego CSW.

Autonomia sztuki i świata sztuki dodatkowo prowokuje do nieustannego ponawiania prób jej sforsowania: zbliżenia się do rzeczywistości, roztapiania sztuki w rzeczywistości. Dzieła sztuki wyglądają jak rzeczywiste obiekty, działają jak rzeczywiste obiekty, ale właśnie dlatego nimi nie są (co oznacza, że nie przeszłyby słynnego testu kaczki wprowadzającego w życie/ilustrującego rozumowanie abdukcyjne - „Jeśli coś wygląda jak kaczka, pływa jak kaczka i kwacze jak kaczka, to jest to prawdopodobnie kaczka"). Podobnie zresztą ma się rzecz z historią sztuki. Jest dyscypliną, której status staje się słabszy, im silniejsze staje się celebrowanie na jej terytorium momentów autonomii: wyjątkowość przedmiotu badań, swoistość metod i tradycji dyscyplinarnych, niepodważalną rolę w zakresie organizacji systemu instytucjonalnego z jego punktami węzłowymi: muzeami, targami i biennale, i podtrzymywania systemu kreacji wartości w ramach globalnego systemu sztuki. Podtrzymywanie autonomii dyscyplinarnej stoi w sprzeczności z mechanizmami tworzenia znaczeń w sztuce współczesnej, z logiką pracy kuratorskiej i działań instytucji sztuki.

Praktyka artystyczna Hito Steyerl jest ceniona bardzo wysoko właśnie dlatego, że - wbrew tendencjom do autonomizacji, właściwym zawsze zarówno instytucjom sztuki, jak i w obsługującym je dyskursom - doskonale odpowiada na konieczność otwarcia terytorium sztuki na rzeczywistość. W tym sensie jest doskonałą odpowiedzią na sformułowany przez Nicolasa Bourriauda w książce The Exform wymóg realizmu. Francuski kurator, krytyk i teoretyk, autor terminu „estetyka relacyjna”, odwołuje się do dobrze ugruntowanej marksistowskiej terminologii, by przeformułować samo pojęcie realizmu:

Rzeczywistość to świat fenomenów w tej mierze, w jakiej stanowi on podstawę dla reprezentacji; żyjemy w niej jako podmioty ideologiczne, 
dzięki członkostwu/przynależeniu oraz podporządkowaniu. Tymczasem realne może być zdefiniowane jako ten sam świat fenomenów, ale uwolniony od ideologii i impulsów idealizacji. To, co zostanie opisane jako realizm artystyczny, nie ma więc nic wspólnego z właściwą artystom zdolnością ukazywania widzialnej czy inteligibilnej rzeczywistości. Nie może być mylony z formatem dokumentalnym czy gatunkiem dokumentu, które od końca dwudziestego wieku uchodzą za nec plus ultra w kwestii przywracania/reprodukcji rzeczywistości. ${ }^{4}$

Bourriaud usiłuje zdefiniować realizm, bazując na różnicy między realnym i rzeczywistością. Realizm jest tu pomyślany jako postawa par excellence krytyczna, bowiem do jego zaistnienia konieczna jest krytyka ideologii, wzniesienie się ponad świat fenomenów, w którym nasze doświadczenie świata ograniczone jest do reprezentacji podporządkowanych narzuconemu nam światopoglądowi. Bycie realistą jest możliwe dzięki doświadczeniu realnego, poza ideologią i idealizmem. Stąd istotą postawy realistycznej w sztuce nie jest wierność pewnemu sposobowi odzwierciedlania rzeczywistości, określonemu kanonowi przedstawiania, lecz wierność wymogowi realizmu, nacisk na doświadczenie realnego.

Bourriaud w bardzo klarowny sposób dystansuje się wobec wszelkich odmian postawy idealistycznej. Chce promować postawę realistyczną i materialistyczną, tzn. taką, w ramach której sztuka odwróci się od ideału imitacji tego, co transcendentne, i zacznie eksperymentować z materią świata. Celowo zwracam tu uwagę na różnicę między imitacją i eksperymentowaniem - o ile w pierwszym przypadku chodzi o relację reprezentacji, której efektem może być jedynie niedoskonałe odzwierciedlenie pierwowzoru, o tyle w drugim istotą jest praca z materią będąca warunkiem możliwości jej doświadczenia. Stąd bierze się dystans Bourriauda wobec najbardziej rozpowszechnionego sposobu myślenia o realizmie: imitowanie rzeczywistości jest wciąż elementem postawy idealistycznej. Francuski kurator i krytyk przeinterpretowuje w swoim duchu całą tradycję realistyczną, poczynając od Courbeta - to francuski malarz staje się figurą przełomu, po którym w sztuce materia pojawia się już na pełnych prawach. W perspektywie Bourriauda sztuka po Courbecie, przynajmniej ta istotna, relewantna, skoncentrowana na doświadczeniu realnego, jest sztuką przepracowującą materię. Z biegiem czasu owa materia okazuje się coraz bardziej związana z rozwijającym się systemem

4 N. Bourriaud The Exform, trans. E. Butler, Verso, London-New York 2015, s. 76. 
kapitalistycznym; im bliżej współczesności, tym większe znaczenie mają materialne resztki systemu, to, co pozostaje poza systemem produkcji. „Materia odsłania realne globalizmu: świat nawiedzany przez widma tego, co nieproduktywne i niezyskowne, wojna przeciw wszystkiemu, co jeszcze nie pracuje lub nie jest przygotowywane do pracy. Na naszych oczach dziedzina odpadów staje się coraz większa. Obejmuje teraz to wszystko, co opiera się asymilacji odrzucone, nieużyteczne i niemożliwe do użycia..."5. Artystyczny realizm musi mierzyć się z wszystkim, co nie daje się zredukować do funkcji w ramach systemu kapitalistycznego. Rzecz jasna, materia może być użyteczna, może funkcjonować jako surowiec, lokata kapitału albo towar. Ale z perspektywy przyjętej przez francuskiego krytyka traci ona wtedy realność - materialność wiąże się nierozłącznie ze statusem naddatku w systemie.

Bourriaud wskazuje, co i kto pozostaje na marginesie dominującego systemu produkcji - ta pozycja może dotyczyć równie dobrze ludzi. Jego punktem wyjścia jest rozpoznanie o niemal nieograniczonym charakterze zasady akumulacji kapitału: łatwo więc domyślić się, jacy ludzie i jakie kategorie rzeczy znajdują się poza systemem. Bourriaud pisze o niemożliwych do powtórnego wykorzystania masach materii powstających w ramach produkcji dóbr, śmieciach i odpadach, ale też o imigrantach (ludziach pozostających poza zasadą akumulacji na skutek przemieszczeń ludności wywołanych kryzysami ekologicznymi, humanitarnymi czy wojnami), bezrobotnych i bezdomnych. Jakkolwiek dyskusyjne może wydawać się to zestawienie (które sprawia wrażenie skonstruowanego dla wywołania reakcji afektywnej), czytelna jest logika, którą kieruje się krytyk. Zadania, które stawia sztuce, wywodzą się wprost z wyżej nakreślonych podziałów. Bardzo instruktywne są Bourriaudowskie interpretacje kilku dzieł sztuki współczesnej ilustrujące pracę z tym, co realne. Praca Maurizio Catellana z 1993 roku zatytułowana Lavorare è un brutto mestiere [Praca to brudna robota)] ma pokazywać dominujące mechanizmy wytwarzania wartości, przy czym jej „materią” jest przestrzeń weneckiego Biennale: artysta odsprzedał agencji reklamowej prawo do korzystania z pawilonu, a ta wykorzystała nabytek do własnych celów. „[...] artysta zrezygnował z jakiegokolwiek symbolicznego żądania, w ramach którego mógłby odsłonić struktury produkcji na rzecz pewnego rodzaju realizmu (w tym przypadku ocierającego się o cynizm), który wciela jego pracę w zwykły bieg

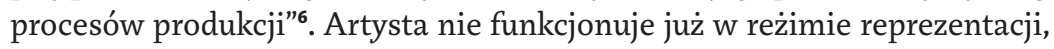

\footnotetext{
5 Tamże, s. VIII.

6 Tamże, s. 90.
} 
nie odsłania tego, jak w rzeczywistości wygląda system kapitalistyczny, lecz wpisuje się w niego, używa jego reguł, pozwala im wniknąć do świata sztuki. Realizm nie polega więc w tym przypadku na zdystansowanej i dystansującej krytyce; jego istotą jest wytworzenie wewnątrz świata sztuki bezpośredniego doświadczenia tego, co realne, $\mathrm{w}$ tym przypadku, absolutnego utowarowienia przestrzeni. Bardziej literalnym przykładem dzieła realistycznego przywoływanym przez Bourriauda jest Penske Work Project Gabriela Orozco z 1998 roku: cykl efemerycznych rzeźb powstałych z odpadów znalezionych w śmietnikach podczas przejażdżki samochodem. Pozostaje po nich jedynie dokumentacja fotograficzna; materialność rzeźb ma bardzo specyficzny charakter, ponieważ jest zdeterminowana przez strategię artysty, który w wyborze obiektów zdawał się na przypadek. Odpady przemysłowe i zwykłe śmieci zamieniają się dzięki gestowi artysty w obiekty artystyczne obdarzone ulotnym pięknem. W ramach Penske Work Project Orozco nie pokazuje śmieci, lecz przekształca ich status, zmieniając jednocześnie to, w jaki sposób mogą być doświadczane. Podobnie jak w przypadku działania/instalacji Catellana, logika przedstawienia ustępuje miejsca strategii pracy z doświadczeniem tego, co realne.

Interpretacje Bourriauda pozwalają na ożywienie pojęcia realizmu i na wypracowanie nowego sposobu patrzenia na sztukę współczesną. Jednak francuski autor nie mierzy się w swojej książce z przekształceniami rzeczywistości, do których dochodzi dzięki technologiom cyfrowym. Choć pokrótce wspomina o roli platform internetowych, takich jak Youtube czy Tumblr, w procesie archiwizacji treści kultury, nie bierze cyfrowości pod uwagę, gdy zaczyna mówić o sztuce. Wszystkie dzieła, które analizuje, należą do epoki analogowej i nie tematyzują cyfrowości. I właśnie z tego powodu ujęcie Bourriauda domaga się uzupełnienia przez analizy takich praktyk artystycznych jak propozycje Hito Steyerl. Praktyka artystyczna i pisarska Steyerl może zostać ujęta jako realizm cyfrowy: zapis doświadczenia tego, co realne, ale $\mathrm{w}$ warunkach zmienionych przez transformację cyfrową. To Steyerl pozwoli nam zapytać o status pracy, tego, co nieproduktywne w epoce cyfrowej, o to, w jaki sposób cyfrowość ułatwia utowarowienie pracy, o to, jak jest ona wykorzystywana w walce z nieproduktywnością. Ukuty przez nią termin cyrkulacjonizm, mający odwoływać się do sposobu funkcjonowania obrazów w epoce cyfrowej, nie jest tylko i wyłącznie terminem opisowym. Ma nieść w sobie obietnicę ingerencji w obieg obrazów.

Musimy pytać o to, jak zorganizowane są obiegi obrazów i do kogo właściwie należą? Kto jest właścicielem infrastruktury? Czyjego wi-fi 
używamy? Jakie są materialne połączenia w obrębie sieci i pomiędzy węzłami? Jakie są relacje władzy w ramach samej infrastruktury? ${ }^{7}$

Tego rodzaju refleksja jest w działalności Steyerl bazą postawy realistycznej. Krytyka i realizm zazębiają się albo wzajemnie się napędzają; oscylacja między tekstami i dziełami, o której wspominałem wcześniej, jest tu odzwierciedlona na innym poziomie. Steyerl w swoich tekstach identyfikuje problemy, nazywa je, tworzy pojęcia; ale jej realizm dochodzi w pełni do głosu dopiero w realizacjach artystycznych, w których nie idzie już o „pokazywanie” rzeczywistości, o wytworzenie reprezentacji jakiegoś stanu rzeczy, ale o wytworzenie warunków możliwości doświadczenia tego, co realne. Doskonałym przykładem jest znana instalacja zatytułowana Strike z 2010 roku, krótki, kilkudziesięciosekundowy film pokazujący artystkę uderzającą w ekran ciekłokrystaliczny. Pojedyncze uderzenie klinem sprawia, że na ekranie pokazuje się sieć pikseli. „Strike” - zgodnie ze swoim znaczeniem w angielszczyźnie - to równocześnie uderzenie, zachęta do uderzenia („strike” oznacza też „uderz") i odmowa pracy: strajk polega w tym przypadku na odmowie pracy i akcie zniszczenia ekranu jako narzędzia pracy niematerialnej, rzeczy służącej do oglądania treści reklamowych. Steyerl nie przedstawia stanu rzeczy, od którego należałoby się zdystansować i dla którego mielibyśmy obowiązek wytworzyć alternatywę. Bardziej istotna jest dokonywana w praktyce, materialna ingerencja w sposób funkcjonowania obrazów cyfrowych. Tytułowe uderzenie jest skierowane przeciw ekranowi - infrastrukturze umożliwiającej udział w cyrkulacji treści cyfrowych. Piksele tworzą jedyny obraz, który widzimy na ekranie, ale rzecz jasna, nie jest to obraz sensu stricto: różnokolorowe linie świadczą tylko i wyłącznie o zniszczeniu obiektu. Infrastruktura staje się widoczna dopiero wtedy, gdy przestaje działać, zupełnie jak narzędzia z Heideggerowskich analiz dotyczących poręczności. Ekran staje się widzialny, ujawnia się jako infrastruktura konieczna do tego, by istniały obrazy w formie cyfrowej. Sfilmowany w pracy gest Steyerl ma charakter realistyczny właśnie dlatego, że jest on u źródeł zdarzenia, w ramach którego ujawniają się materialne warunki możliwości istnienia dominującej obecnie formy wizualności. Ów realizm oferuje jednocześnie możliwość krytyki, pozwala na gest krytyczny albo wręcz zachęca do niego, do ingerencji w infrastrukturę porządku reprezentacji.

$7 \quad Ł$.Zaremba Działać jako piksel... 
W nieco późniejszym tekście zatytułowanym Spam Ziemi. O wycofaniu sie z reprezentacji Steyerl rozwija motyw pragnienia dystansu wobec reprezentacji wizualnych:

Przepowiednia Warhola, że każdy będzie sławny przez piętnaście minut, już dawno stała się prawdą. Dziś wielu ludzi pragnie przeciwnego - chcą być niewidzialnymi, choćby przez piętnaście minut. Nawet piętnaście sekund byłoby czymś. [...] Dlatego tak wielu ludzi odchodzi dziś od wizualnej reprezentacji. Instynkt (i inteligencja) podpowiadają im, że obrazy fotograficzne i filmowe są niebezpiecznymi narzędziami przechwytywania - czasu, uczucia, sił wytwórczych i podmiotowości. Mogą cię uwięzić lub zhańbić na zawsze. Mogą zamknąć cię w monopolu twardych dysków i labiryntach konwersji. ${ }^{8}$

Na przykładzie powyższego fragmentu doskonale widać, w jaki sposób działa w praktyce omawiana przeze mnie oscylacja między dziełami artystycznymi i tekstami w działalności Steyerl. Strike było wizualnym zdarzeniem, konkretną ingerencją w rzeczywistość i równocześnie zachętą do ingerencji. W tekście artystka powraca do analizowanego problemu, pogłębia go i wpisuje w szerszy kontekst historyczny: w przemiany obiegu medialnego od epoki przemysłowej do współczesności. O ile jeszcze kilkadziesiąt lat temu posiadanie wizerunku medialnego było czymś pożądanym (jako dobro rzadkie), o tyle teraz obrazy są narzędziami kontroli i dominacji, a nawet częścią systemu, w ramach którego poświęcamy swoją energię i afekty na rzecz mechanizmów tworzenia wartości, o których czasem nie mamy nawet pojęcia.

Instalacja Steyerl zatytułowana Red Alert z 2007 roku składa się z trzech identycznych, zawieszonych w równych odległościach od siebie paneli LCD, na których wyświetlany jest film. Jednak każda klatka tego filmu wygląda tak samo - to monochromatyczny obraz w kolorze czerwieni używanej przez amerykańskie Homeland Security na oznaczenie najwyższego stopnia zagrożenia bezpieczeństwa. Praca zarówno na poziomie znaczeniowym, jak i formalnym gra z wymogiem realizmu. Czytelne jest w jej przypadku nawiązanie do tryptyku Rodczenki Czyste Kolory: Czerwony, Żótty, Błękitny z 1921

8 H. Steyerl Spam Ziemi. O wycofaniu się z reprezentacji, przeł. Ł. Zaremba, "Widok. Teorie i Praktyki Kultury Wizualnej" 2014 nr 5, http://widok.hmfactory.com/index.php/one/article/ view/179/271 (12.03.2020). 
roku, mającego symbolizować logiczny kres malarstwa. Proporcje paneli i ich wzajemne usytuowanie są powtórzeniem gestu malarza. Różnica leży gdzie indziej: Steyerl nie analizuje logiki malarstwa, nie dociera do jego niezmiennych praw, lecz zajmuje się tym, co najbardziej realne: używa barwy mającej natychmiastowo przykuwać uwagę w sytuacji zagrożenia. Ostrzegawcza czerwień zapowiada katastrofę, kres świata, jaki znamy. Film składający się z jednakowych klatek w każdym momencie wygląda tak samo - cyrkulacja obrazów jest tu jednocześnie niewidzialna (ponieważ nie sposób zauważyć tego, że mamy do czynienia z filmem, a nie nieruchomym obrazem) i wszechobecna (ponieważ warunkuje naszą możliwość obejrzenia pracy). $Z$ tego powodu można stwierdzić, że film problematyzuje mechanizm cyrkulacji. Pozwala zobaczyć, że leży on u podstaw wszelkiego doświadczenia obrazu (cyfrowego), nawet jeśli sama cyrkulacja nie jest bezpośrednio widzialna.

Z perspektywy Steyerl kluczowym elementem doświadczenia cyrkulacji obrazów powinny stać się tzw. nędzne obrazy. Mają one stanowić alternatywę dla obrazów dominujących w ikonosferze: funkcjonują w innych obiegach, są traktowane jako rodzaj zaburzenia w porządku wizualności.

Nędzny obraz to łachman lub skrawek; AVI lub JPEG, lumpenproletariusz w klasowym społeczeństwie wyglądów, zaszeregowany i oceniany według swojej rozdzielczości. Nędzny obraz został załadowany, ściągnięty, podlinkowany, przeedytowany i przeformatowany. Zamienił jakość na dostępność, wartość ekspozycyjną na wartość kultową, film na klip, kontemplację na rozproszenie. Obraz taki został uwolniony ze skarbców kin oraz grobowców archiwów i wrzucony w obszar cyfrowej niepewności, za co zapłacił swoją własną substancją. ${ }^{9}$

Niska jakość nędznych obrazów, ich podrzędność, niemożliwość podporządkowania ich logice spektaklu sprawiają, że nie kierują one naszej uwagi na same siebie, lecz na procesy cyrkulacji. W tym sensie pozwalają doświadczyć cyfrowego realnego: zależności obrazów od procesów łączenia się, montowania, przesyłania, kopiowania.

Choć teksty i dzieła Steyerl dotyczące logiki działania obrazów stanowią najznaczniejszą część jej dorobku, w kontekście pytania o realizm i o możliwość relewantności praktyki artystyczno-badawczej absolutnie kluczowy

9 H. Steyerl W obronie nędznego obrazu, przeł. Ł. Zaremba, "Konteksty. Polska Sztuka Ludowa” $2013 \mathrm{nr}$ 3, s. 101. 
wydaje mi się esej zatytułowany Czy muzeum to fabryka? mówiący o instytucji muzealnej w relacji do przestrzeni fabrycznych. Jego istotą jest jednak co innego: Steyerl pisze w gruncie rzeczy o tym, w jaki sposób tworzona jest wartość w najbliższym nam stadium kapitalizmu.

Artystka rozpoczyna od zwrócenia uwagi na symptomatyczną dla współczesności zmianę w sposobie i miejscu prezentowania filmów zaangażowanych politycznie. O ile w epoce przemysłowej były one prezentowane w fabrykach i służyły jako jeden z elementów formowania identyfikacji klasowej robotników, o tyle w epoce zmierzchu przemysłu na szeroko rozumianym Zachodzie trafiają do przestrzeni muzealnych: „Dziś zarówno polityczne, jak i eksperymentalne filmy są pokazywane w czarnych pudełkach umieszczonych w białych kubikach - w fortach, bunkrach, dokach i dawnych kościołach. Dźwięk jest niemal zawsze okropny. Jednak mimo strasznych warunków projekcji prace te cieszą się zdumiewającym zainteresowaniem"10. Hito Steyerl pisze o nowych przestrzeniach muzealnych z wyraźną niechęcią; łatwo zrekonstruować rys afektywny jej perspektywy, w której poczucie konieczności zaangażowania politycznego miesza się z poczuciem rozczarowania logiką rozwoju sytuacji. Coraz trudniej mówić o zaangażowaniu jako pracy nad świadomością ściśle określonej grupy społecznej. Jednocześnie komplikacji ulega sam sposób prezentacji filmów; eliptyczna uwaga Hito Steyerl o "strasznych warunkach projekcji” ma przywodzić na myśl doświadczenia ekspozycji, na które składa się nieskończona wielość obrazów i dźwięków. Wystawy funkcjonują w wielkoskalowych przestrzeniach galeryjnych i muzealnych; ich rozmiary, wprost proporcjonalne do wzrostu produkcji artystycznej, wydają się niemal nieograniczone. Widz staje na przegranej pozycji wobec nadmiaru repertuaru, ilości i natężenia wrażeń. Popularnym submedium pracy artystycznej stały się multimedialne instalacje wykorzystujące techniki filmowe, ale często w nadmiarowej, zwielokrotnionej formie; projekcje filmu sprawiające, że widz pozostaje unieruchomionym, statycznym podmiotem skupionym na deszyfracji znaczeń, stają się rzadkością. Ich miejsce zajmują instalacje i formaty ekspozycji generujące doświadczenie rozproszenia. Jedyną stałą sytuacji wystawienniczej wydaje się nadmiar bodźców. Denuncjowane przez Steyerl warunki pokazywania materiałów filmowych nie wydają się nam już niczym dziwnym - stanowią raczej warunek możliwości współczesnego doświadczenia sztuki. 
Muzealne i galeryjne instalacje często składają się dziś z wielości konkurujących ze sobą obrazów i prezentacji, które zastępują jednozbiegową perspektywę klasycznego kina, uwalniają widza z zamkniętego, diegetycznego, iluzyjnego wszechświata i wpływają na jego zachowanie w przestrzeni ekspozycyjnej, podważając „fałszywą absolutyzację czasu, do której skłonne jest kino"."1

Komentarz Leighton przeciwstawia sytuację widza wobec współczesnej instalacji i wobec kina klasycznego. Doświadczenie kina klasycznego miało mieć charakter iluzyjny: zgodnie z teorią aparatu Jeana-Louisa Baudry'ego opiera się ono na odcięciu widza od rzeczywistości i podporządkowaniu go temu wszystkiemu, co składa się na aparat filmowy.

Widz, wkraczając do ciemnej sali kinowej, akceptuje własne dobrowolne uwięzienie w krześle. Jego nieruchomość uniemożliwia osobistą kontrolę tego, co właśnie się dzieje, i powoduje, że cienie na ścianie jaskini (obrazy na ekranie kinowym) brane są za rzeczywistość. [...] Projektor tworzy iluzję w sposób bardzo precyzyjny. Nie tylko dlatego, że wytwarza obrazy, lecz przede wszystkim dlatego, że wytwarza specyficzne podmioty w takim zakresie, w jakim podmiot jest integralną częścią aparatu. ${ }^{12}$

Tymczasem dominacja formatu instalacji sprawia, że sytuacja iluzyjna zostaje zakwestionowana. Technicznie jest wciąż jeszcze możliwa, być może nawet łatwiejsza do urzeczywistnienia dzięki postępowi technicznemu. Ale logika rozwoju formatów tworzenia i eksponowania sztuki idzie - jak się wydaje w innym kierunku. Jak mówi Leighton, w wykorzystywanych obecnie przestrzeniach wystawienniczych wrażenia stają się wobec siebie konkurencyjne, wchodzą w konflikty, nachodzą na siebie; w tekście Steyerl nietrudno wyczuć nieufność wobec tego stanu rzeczy, jak gdyby powodowała nią nostalgia za muzeum (lub raczej fabryką), w której filmy polityczne zajmowały całą uwagę wciąż prepolitycznych podmiotów. Artystka prawdopodobnie nie podziela krytycznego optymizmu Leighton, która zakłada, że uwolnienie widza od iluzji kinematycznej może mieć wartość emancypacyjną.

11 T. Leighton Introduction, w: Art and the Moving Image. A Critical Reader, ed. by T. Leighton, Tate Publishing and Afterall, London 2008, s. 29.

12 A. Helman Psychoanalityczna teoria filmu, w: A. Helman, J. Ostaszewski Historia myśli filmowej. Podręcznik, słowo/obraz terytoria, Gdańsk 2007, s. 249. 
Zdaniem Steyerl przeniesienie filmów zaangażowanych politycznie do przestrzeni muzealnych nie jest równoznaczne z potocznie pojmowaną muzealizacją; innymi słowy, ten proces nie skutkuje całkowitą sterylizacją produkcji artystycznej, nie sytuuje jej poza rzeczywistością współczesnego kapitalizmu. Wręcz przeciwnie: dzięki temu, że filmy trafiły do przestrzeni muzealnych, znajdują się tak naprawdę w sercu kapitalistycznej logiki produkcji.

przemieszczenie filmów z fabryki do muzeum tak naprawdę nigdy się nie dokonało.W rzeczywistości filmy polityczne pokazywane są w dokładnie tych samych miejscach, co dawniej: w byłych fabrykach, które dziś dość często są muzeami. [...] Mamy więc do czynienia z fabryką, ale inną. To nadal przestrzeń produkcji, przestrzeń wyzysku, a nawet politycznych pokazów. ${ }^{13}$

Steyerl ujawnia w tym miejscu właściwą stawkę swojego tekstu. Jej początkowe obserwacje mówiące o faktycznej depolityzacji aktywności artystycznej, o oderwaniu sztuki od kontekstu społecznego są tylko tłem dla kluczowej diagnozy: uczestnicy pola sztuki tak naprawdę nie stają się marginalnymi aktorami społecznymi, nie są spychani na peryferia współczesnego kapitalizmu, lecz funkcjonują w samym jego centrum. Innymi słowy, muzea nie są sanktuariami twórczości niezależnej od dominującego sposobu organizacji stosunków ekonomicznych, lecz raczej laboratoriami, w których eksperymentuje się (zwykle zresztą nieświadomie) z najbardziej efektywnymi sposobami wytwarzania wartości. Fabryka jest emblematyczną przestrzenią naszego fragmentu nowoczesności: muzeum o wiele lepiej ucieleśnia to, w jaki sposób działa kapitalizm. Artystka wpisuje się w formułowane w socjologii wizje współczesności skoncentrowane na procesach estetyzacji świata. Nie sposób nie czytać Steyerl bez odwołania do tez Gilles'a Lipovetsky’ego i Jeana Serroya, którzy w książce poświęconej „estetyzacji świata"14 postulują odejście od modelu myślenia o społeczeństwie bazującym na podziale na gospodarkę i kulturę. Gospodarka jest przeniknięta tym, co estetyczne, a kapitalistyczny sposób produkcji nie powinien być myślany (przynajmniej nie w pierwszej kolejności) jako siedlisko wszelkiego zła, przed którym bronić się albo szukać ucieczki można tylko w kulturze. Stwierdzenie,

13 H. Steyerl Czy muzeum to fabryka?, s. 99-100 [przekł. zmodyfikowany].

14 Zob. G. Lipovetsky, J. Serroy L'Esthétisation du monde, vivre à l'âge du capitalisme artiste, Gallimard, Paris 2013. 
zgodnie z którym kapitalizm posługuje się estetyką albo ma właściwą sobie estetykę, nie wydaje się specjalnie kontrowersyjne; brzmi raczej jak truizm. Nowością w analizach Gilles'a Lipovetsky'ego i Jeana Serroya jest nakreślenie perspektywy, w której proces estetyzacji okazuje się absolutnie centralnym zjawiskiem obecnej fazy kapitalizmu: nie da się myśleć bez niego procesów ekonomicznych, zwłaszcza w krajach wysoko rozwiniętych.

Równie celny kontekst dla pracy Steyerl nakreślają Luc Boltanski i Arnaud Esquerre, którzy piszą o efektach dezindustrializacji w krajach Europy Zachodniej i Ameryki Północnej. Migracja produkcji przemysłowej do krajów, w których siła robocza jest o wiele tańsza, wytworzyła brak w systemie kreacji wartości. Kapitalizm epoki przemysłowej, oparty na wielkoskalowej produkcji dóbr i dążeniu do redukcji kosztów i, co za tym idzie, cen, musi zostać zastąpiony przez porządek alternatywny. Zdaniem francuskich socjologów jesteśmy świadkami systemowej zmiany, w ramach której kształtuje się system kreacji wartości oparty na wyjątkowości pewnych kategorii dóbr.

Fascynacja,którą wedle powszechnego uznania powinny one wzbudzać, miałaby być związana z pewnego rodzaju aurą jaka je otacza, nadającą im wyjątkowy charakter i predestynującą do bycia czymś elitarnym. Przedmiotami, o których tu mowa, mogą być antyki, rzeczy wytwarzane przez producentów towarów luksusowych [...]. Do tej grupy mogą też należeć dzieła sztuki współczesnej eksponowane w galeriach, na targach albo aukcjach, które przyciagają uwagę ze względu na swój aspekt kulturowy, ale także ekonomiczny. ${ }^{15}$

Wydaje się na pierwszy rzut oka, że najważniejsza w analizach francuskich socjologów jest zmiana skali: o ile w gospodarce przemysłowej z okresu dojrzałego kapitalizmu chodziło o efektywność produkcji wielkiej ilości dóbr zaspokajających potrzeby jak najszerszych grup konsumentów, o tyle w nowym, kształtującym się systemie w centrum znajdują się obiekty rzadkie, czasem nawet pojedyncze, takie jak dzieła sztuki, wyjątkowe nieruchomości, zabytki. Tym samym Boltanski i Esquerre uzupełniają istniejące już w ekonomii teorie dotyczące kształtowania się cen dóbr o ograniczonej dostępności o dane dotyczące geograficznej parcelacji produkcji w warunkach dojrzałej globalizacji; zdaniem socjologów dotykające przede wszystkim Europę osłabienie modelu

15 L. Boltanski, A. Esquerre Kolekcjonerstwo jako nowa forma kapitalizmu. Kapitalizacja przeszłości i jej skutki, oprac. i przeł. M. Warchala, „Kronos. Metafizyka, Kultura, Religia” 2015 nr 2, s. 126. 
produkcji bazującego na wytwarzaniu serii obiektów standardowych musiało pociągnąć za sobą pojawienie się alternatywy.

Siłą rzeczy, obiekty powstające w ramach nowego porządku wytwarzania wartości nie są przedmiotem konsumpcji szerokich grup społecznych. Ich wyjątkowość stawia je poza zasięgiem większości konsumentów; dla nich pozostają jedynie źródłem pragnienia. Boltanski i Esquerre uznają, że w nowym systemie kluczowe stają się procesy wzbogacania rzeczy.

Gospodarce skupionej na produkcji przemysłowej można przeciwstawić gospodarkę opartą na czymś, co nazwiemy wzbogacaniem rzeczy. [...] Termin „wzbogacanie" powinien być tu rozumiany w znaczeniu, w jakim mówimy o „wzbogacaniu” metali, ale też o wzbogacaniu życiowego otoczenia, sposobu ubierania się, zasobów kulturowych albo pewnego zestawu przedmiotów. ${ }^{16}$

Wzbogacanie jest możliwe w przypadku niektórych klas przedmiotów; jedną z nich jest sztuka. W rozważaniach Boltanskiego i Esquerre'a zajmuje ona istotne miejsce; jak sygnalizowałem wcześniej, to na tym polu system kreacji wartości jest najbardziej efektywny. Sztuka po Duchampie jest polem nieograniczonym przedmiotowo, wszystko może wejść w jej skład: jej wartość nie jest ściśle związana z materialnymi własnościami obiektów, niekiedy jest od nich absolutnie niezależna. Oznacza to, że proces wzbogacania w obszarze sztuki może odbywać się wyjątkowo sprawnie. Dowolny obiekt może zostać ready-made: dojmującym przykładem tego zjawiska jest pokazany na zeszłorocznym weneckim biennale statek, na którym 18 kwietnia 2015 roku zginęło kilkuset migrantów usiłujących przedostać się z Libii do Europy. Został uznany za dzieło sztuki i przetransportowany na teren biennale przez zespół kierowany przez szwajcarskiego artystę Christopha Büchela. Stał się dziełem sztuki dzięki ich pracy, został przepracowany, przeniesiony w inny kontekst i w odmienne otoczenie instytucjonalne. Wytworzone dzięki gestom Duchampa warunki możliwości funkcjonowania sztuki sprawiają, że artystyczne sposoby tworzenia wartości wydają się szczególnie efektywne. Dlaczego? O ile w przypadku niektórych kategorii dóbr, do których odnoszą się w swoich analizach Boltanski i Esquerre, można łatwo doszukiwać się bezpośredniego związku między jakościami materialnymi rzeczy i jej ceną (tak jest choćby w przypadku przynajmniej niektórych obiektów z pola mody czy designu, przedmiotów 
luksusowych tworzonych z drogich materiałów i przy użyciu kosztownych technik), o tyle w sztuce możliwe są niezwykle efektywne procesy tworzenia wartości mimo relatywnego braku solidnych podstaw materialnych. Innymi słowy, w sztuce możliwa jest sytuacja, w której cena konkretnego obiektu będzie niezwykle wysoka, mimo że sam obiekt nie jest wyjątkowy ze względu na swoje cechy materialne; oczywiście w takim przypadku jego wartość ma swoje podstawy, ale gdzie indziej: w umiejscowieniu historycznym, w związku z przełomową praktyką czy ideą artystyczną, w byciu częścią znaczącej kolekcji,w dominującej narracji porząadkującej pole sztuki.

Hito Steyerl analizuje współczesną kondycję artystyczną, która wciąż znajduje swoje źródło w gestach Duchampa: wpisuje się w nią w ramach swojej praktyki i równocześnie opisuje jej warunki możliwości w kolejnych esejach. Mimo że znana jest przede wszystkim jako autorka prac wideo, istotną cechą jej działalności jest wykorzystanie obiektów o bardzo różnej proweniencji do tworzenia złożonych instalacji, w których industrialne materiały organizujące przestrzeń są równie istotne, co same materiały filmowe. Instalacja Hell Yeah We Fuck Die, przygotowana na Skulptur Projekte Münster w 2017 roku, składa się z filmów pokazujących eksperymenty na humanoidalnych robotach. Poświęcona jest więc explicite pracy, jej przyszłości, sposobowi wytwarzania wartości w gospodarce o wysokim stopniu automatyzacji. Równocześnie instalacja inkorporuje materiały - płachty blachy falistej i metalowe rurki które wpisują widza w przestrzeń produkcji znaczeń i wartości kojarzącą się z epoką przemysłową. Innymi słowy, w tym przypadku Steyerl jednocześnie wskazuje na zmiany w procesie kreacji wartości (temu poświęcone są filmy) i odgrywa je, wciągając oglądającego w przestrzeń ustrukturowaną przez materiały odsyłające do procesów produkcji, wpisując go w proces wytwarzania wartości dzieła.

Tekst Czy muzeum to fabryka? mówi właśnie o tym, w jaki sposób instytucja muzealna funkcjonuje jako miejsce pracy, czyli - to równoznaczne - miejsce wytwarzania wartości.

W muzeum-jako-fabryce dalej się coś produkuje. Instalacje, planowanie, ciesielka, oglądanie, dyskutowanie, utrzymywanie porządku, przewidywanie, czego wartość wzrośnie, i networking następują tu jedno po drugim. [...] W ramach tej ekonomii nawet widzowie zostali przekształceni w pracowników. ${ }^{17}$

17 H. Steyerl Czy muzeum to fabryka?.., s. 100. 
Muzeum-jako-fabryka to po prostu miejsce pracy: miejsce pracy ludzi, dzięki którym rzeczy stają się dziełami, wchodzą w stosowny kontekst instytucjonalny, są oglądane jako dzieła ${ }^{18}$. Ale jest to także sposób organizacji działań mających na celu wytworzenie wartości albo wzbogacenie rzeczy, zarówno przez tych, którzy są związani z muzeum czy galerią za pomocą umów, jak i tych, którzy je odwiedzają, mówią o niej, relacjonują swoją wizytę w mediach społecznościowych. Muzeum okazuje się instytucją, której działanie umożliwia instaurację nowej fazy rozwoju kapitalizmu; wbrew szeroko rozpowszechnionym przekonaniom, zgodnie z którymi muzealizacja jest równoznaczna z marginalizacją treści kulturowych, instytucje sztuki są laboratoriami nowej formy organizacji gospodarki.

\section{Abstract}

\section{Andrzej Leśniak}

THE INSTITUTE OF LITERARY RESEARCH OF THE POLISH ACADEMY OF SCIENCES (WARSAW)

Hito Steyerl: Digital Realism and the Work of the Museum

Leśniak presents an interpretation of selected works and texts by contemporary German artist Hito Steyerl. Drawing on Nicolas Bourriaud's version of the concept of digital realism and the notion of enrichment proposed by Luc Boltanski and Arnaud Esquerre, Leśniak demonstrates that Steyerl's practice is characterised by an exceptional ability to thematise current problems. Her works are not only extremely relevant in the way they refer to problems related to the mechanisms of visuality in the digital age, but also in the way they tackle the functioning of institutions - museums and galleries - as a process of enrichment that is key to the logic of capitalism in the post-industrial era.

\section{Keywords}

digital realism, museum, contemporary art

18 Steyerl od dłuższego czasu zajmuje się kwestią pracy w kontekście muzeum; zob. H. Steyerl The Institution of Critique, w: Art and Contemporary Critical Practice. Reinventing Institutional Critique, ed. by G. Raunig, G. Rau, Mayfly, London 2009. 